Vitaliy Radko

\title{
2.3. MAIN TRENDS AND WAYS OF MILK MARKET DEVELOPMENT IN UKRAINE
}

\begin{abstract}
Summary
In agricultural sphere of Ukraine, there are many problems in the organizational and economic conditions providing for its effective development. It concerns completely the milk production. Formerly the average level of milk consumption has been about $60 \%$ of the scientifically recommended amount. The decrease may be explained by limited buying ability of consumers, the decreased volume of milk production, low raw milk quality etc. The economic efficiency of milk production is very low, therefore agricultural producers are not interested in milk production and it is not attractive for investors. The efficiency is affected by the low level of organization and technological process. The old machinery used for the milking, feeding and stock keeping cannot provide the productivity level of modern requirements. Due to this, the competitiveness of Ukrainian dairy sector is decreasing. The need for modernization of the production process has become a very actual problem under the financial crisis. This situation requires innovative methods of development and efforts of the integration of producers, processing, service companies and other participants of dairy sector.
\end{abstract}

Keywords: market, milk, production, efficiency, price, profitability

\section{Introduction}

Development of national economy depends on the situation in agriculture. In this sphere, the production of animal husbandry products is of great importance. The shortage of financial resources, old machinery, out-of-date capacity, the immigraion of skilled labour and some other reasons have negative influence on the production efficiency. Another problem at the market of agricultural products is quality and safety. Old production technologies, high rates for bank loans make difficult the development and modernization of production processes. As a result, the profitability of many agricultural producers and their competitive ability have decreased. Such situation is similar for Ukrainian milk market.

Problems of efficient agriculture development, quality and safety of agricultural production, its competitive ability are researched in the works of many scientists including Berezivsky, Ilchuk, Kvasha, Sabluk, Shpychak and Svynous. These problems are still actual therefore it became one of the main reasons to choose the subject for the research.

\section{Material and methods}

The main aim of this research is to determine the main trends in milk production and to summarize the prospects of stable formation of milk demand in Ukraine. 
To solve the task of the research such methods were used: economic and mathematic - to take account of the milk production economic efficiency indexes, an analysis and comparison - for economic estimation of main trends at the milk market, a graphic approach - for presentation some data that influence of supply formation.

Main information base of the article were the materials of Ministry of Agricultural Policy of Ukraine, State Service of Statistics, International Farm Comparison Network, the agricultural companies and the researches of different scientists.

\section{Results and discussion}

Important branch of agricultural production is the dairy cattle breeding, which provides consumers by a valuable and irreplaceable food product, which is necessary for maintenance of vital functions and which is characterized by a high food value and irreplaceable component matters. However, today this branch is in a very difficult situation. The gross production volume, the quantity of population of dairy herds, the productivity of cows and the quality of raw milk are at low level. In addition, the level of production substantially depends on the season that also influences the general situation. As a result, processing enterprises are not able to load own production capacities without interruption and to produce the prepared products at high quality and in a competitive way. The use of insufficient technical equipment by the agricultural producers and the out-of-date technologies of processing enterprises increase the costs substantially. In the conditions of the limited purchasing power, the increase of production prices will result a situation, when considerable part of consumers is helpless to satisfy the physiology requirements in dairies and the required level of consumption of milk will decrease. It is inevitable to provide the necessary terms of effective production of milk and to develop certain measures on the improvement of situation in this branch.

Parhomets (2005) suggests that the market of dairy products has specific features which most show up at complete correlation of demand and supply on concrete milk products. Thus, in a certain market situation these features become the dominant factors of mechanism pricing, which substantially influence on forming of demand, suggestion and cost of products. Such factors which determine the features of market of milk products are time, quality, assortment and place of delivery to the products to the consumer. Milk product market is a constituent of food, which unites the sphere of production of milk in the different forms of menage, the industries of purveyance of raw material, the processing and making of milk products and finally, the sphere of realization and consumption. Thus, the market of milk and milk products functions as a computer-integrated subsystem which has the following features: unity of purpose, close productive-technological copulas, organizationally-economic mutual relations, sent to the improvement of social terms of population (Parhomets, 2005, p. 50).

In the past years an unstable situation of milk market has developed. The number of livestock decreased that has resulted a decrease of milk production volume. Although cow productivity has increased but the indices of its increase were less than the indexes of number of cows decrease and it makes negative influence on production volume. 
At the same time, decrease of production concentration according to a number of indices was observed. The major milk volume was produced at individual farms, which were unable to meet the requirements according to European quality standards due to the low level of mechanization and automation of technological processes.

Milk prices have reached the level of European countries but profitability of production remains unstable. In my opinion, it could be explained by the considerable increase of production costs. One of the most important reasons of low economic efficiency is low level of intensification and outcome per cow and one hectare of land.

Low quality of raw milk sold for processing does not allow many dairy plants to produce finished products that could be exported to world markets. It considerably decreases competitive ability of domestic milk branch that affects its economic efficiency.

The following trends could be observed in milk and dairy market development:

- Low economic efficiency of milk production,

- Decrease of milk production volume,

- Small concentration of production,

- Large milk volume is produced by individual rural farms,

- Low raw milk quality,

- Low milk consumption level due to limited consumers' buying ability,

- Milk prices have reached the level of many EU countries,

- Low competitive ability of domestic milk branch.

Famous Ukrainian scientist, Berezivsky, states that modern scientific researches of production organization improvement are the necessary basement of economic efficiency increase (Berezivsky, 1998, p.8).

According to the data of the State Service of Statistics of Ukraine the number of cows decreased more than 1 million heads or 28,9\% during 2005-2011 (Figure 1). Cow productivity increased from $3487 \mathrm{~kg}$ in 2005 to $4174 \mathrm{~kg}$ in 2011 or on $19,7 \%$. It is significant to note that cow productivity in private sector is $15-20 \%$ higher than at agricultural enterprises.

\section{Figure 1.Number of cows and milk productivity in Ukraine}

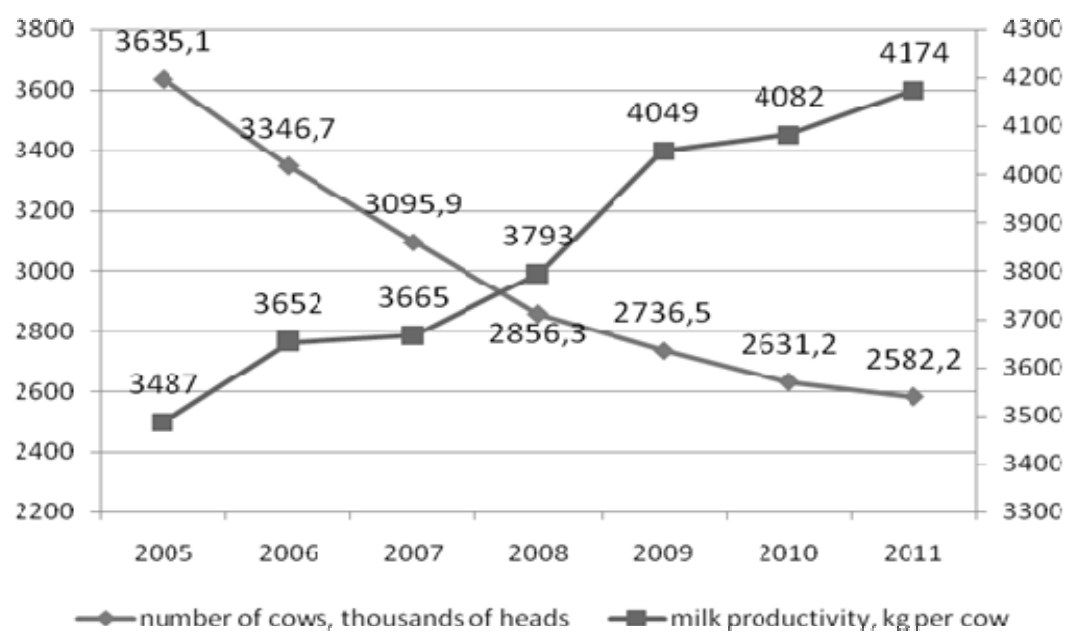

Source: Own research 
In my opinion, it could be explained by the fact that individual farms pay more attention to animal welfare and it affects the level of milk yield. Despite the milk yield increase, an average level of cow productivity in Ukraine is much less than in EU countries.

Some scientists affirm that the level of cow productivity is very low and it cannot guarantee economic efficiency of milk production (Musyka et al., 2010, p.17).

The above mentioned trends leaded to the reduction of total volume of production by almost 2,6 mln tonnes or 19,2\% between 2005-2011 (Figure 2).

The rate of decrease in private sector is almost equal. The share of individual farms in the structure of total milk production was $80 \%$ while agricultural companies represented $20 \%$ in 2011.

Figure 2: Milk production, thousands tonnes

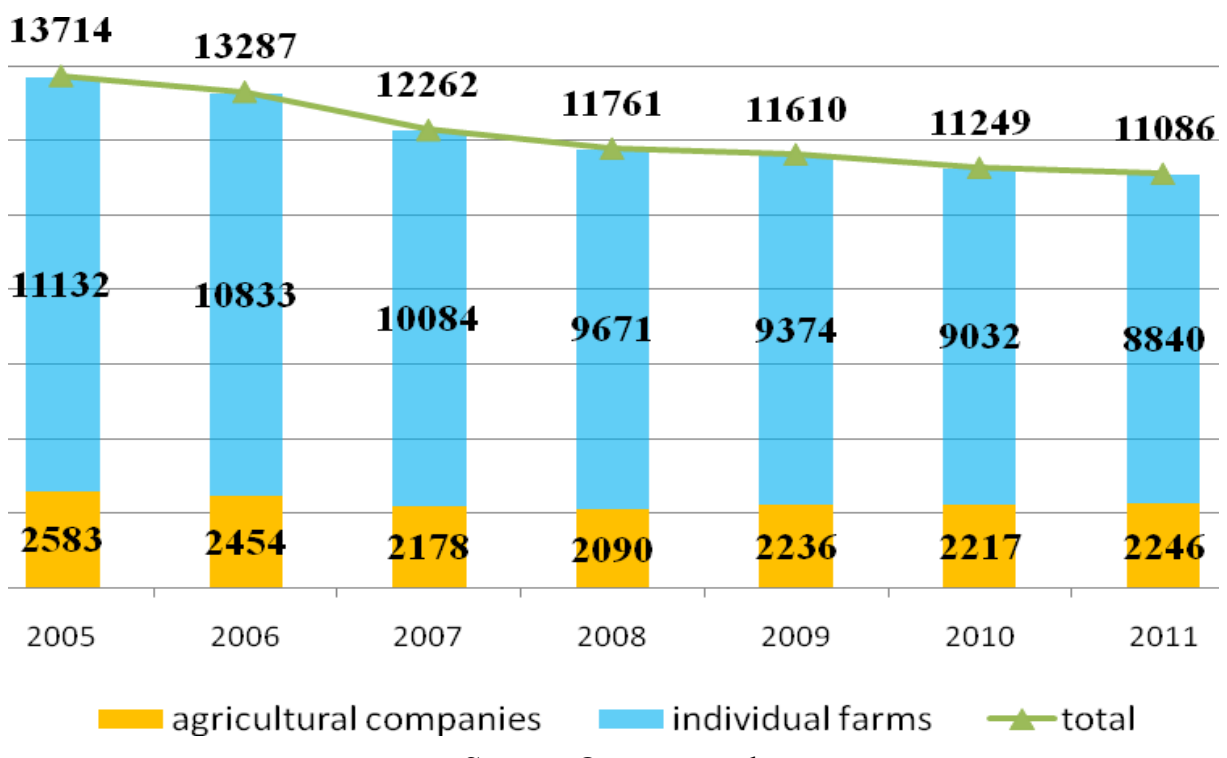

Source: Own research

The concentration in milk production is decreasing. In $2011,22 \%$ of companies had 10 cows and $33 \%$ of them had between 10 and 100 . It is very difficult to use modern technologies of milk production and milking in such situation. $28 \%$ of companies produced up to $2000 \mathrm{~kg}$ of milk per a cow and only $7 \%$ only produced above $6000 \mathrm{~kg}$ as many farmers in EU countries. It is very difficult to cover the production costs with a milk yield about $3000 \mathrm{~kg}$. $44 \%$ of companies produced up to $300 \mathrm{~kg}$ of milk per day. Processing enterprises are not interested in such producers that affect their milk purchasing price.

Decrease of milk production concentration has negative influence on its economic efficiency and it may decrease interest and motivation of producers to keep cows and produce milk. One of the most important reasons is resources shortage for the development and modernization of dairy business.

Scientists state that production development is not a fast and simple process. According to the specific peculiarities of milk production organization, we can suppose that it will take a long period (Sabluk and Boyko, 2005, p.67). 
One of the main problems for processing enterprises there is a low quality of raw milk. As Kravtsiv (2001) marked, one of the most frequent violations, which results in the reducing of quality of milk, is mixing of the cooled milk of evening yield and fresh morning yields. Even at the least of microorganisms in the cooled and fresh milk after their mixing there is a stormy height of microflora, and for short time milk loses the sanitary and hygenic internals as a result of high bacterial colonization, that is why and estimated as low-grade. At mixing of parties of milk, different on a size and cooling degree, quality of the mixed milk goes down the quicker, than anymore is party of the cooled milk. It is explained that intensive development of microflora of the cooled part of milk, the temperature of which rises at mixing, is, that and gives an impulse for the rapid increase of amount of microorganisms. Mixing of milk does not influence on a common colonization only then, when a difference in the temperature of parties of milk, which mixed up, did not exceed $2^{\circ} \mathrm{C}$. It is necessary to be taken into account in practical activity of dairy farms, as a failure to observe of him takes work of all collective on it is not. Shelf-life of milk on farms to transporting to milk processing enterprises at a temperature $4^{\circ} \mathrm{C}$ not must exceed 24 hours, at a temperature $6^{\circ} \mathrm{C}$ it is 18 hours, but at a temperature $8^{\circ} \mathrm{C}$ it is only 12 hours (Kravtsiv et al., 2001).

Low quality of raw milk is also very important problem of milk market function. In $2011,43,7 \%$ of agricultural companies that produced milk could provide a milk raw of high quality, $52,9 \%$ was first quality, $3,3 \%$ was second quality and $0,1 \%$ was unsorted milk.

It should be noted that milk of sort „extra” realized in 2011 only by the agricultural enterprises of seven regions. More than average index in Ukraine $(5,6 \%)$ realized four regions, namely: Sumy, Kherson, Kharkiv and Kyiv. Sumy region had the best index $(16,2 \%)$. The agricultural enterprises of 21 regions realized milk of top grade. Anymore more thanaverage index on Ukraine $(32,9 \%)$ realized six regions: Dnipropetrovsk, Mykolaiv, Vinnytsya, Kyiv, Poltava and Kharkiv. Milk of the first quality was realized less than in the middle of Ukraine $(57,7 \%)$ by agricultural enterprises of 17 regions. At the same time from the agricultural enterprises of Kirovohrad, Chernivtsi, Rivne, Odesa, Volhynia and Khmelnytsk regions acted on processing almost of $100 \%$ (from 99,8 to $92,5 \%$ ) milk of chop. The large enough percent of milk of the second sort was realized by the enterprises of Zhytomyr (20 thousand tonne, or 37,8\%), Kherson $(9,2$ thousand tonne, or $22,7 \%)$ and Ivano-Frankivsk (2,3 thousand tonne, or $16,2 \%)$ regions. Low-grade milk (7,7 thousand tonne) acted on processing enterprises from agricultural enterprises 20 regions, most - from Kyiv (1,4 thousand tonne, or $0,7 \%)$, Vinnytsya (1,2 thousand tonne, or $0,7 \%)$, Ternopil (1 thousand tonne, or $1,6 \%)$.

At the same time there is a big difference between requirements of high quality milk in Ukrainian and European standards. They are approximately the same according to somatic cells (maximum level about 400000 cells per $\mathrm{ml}$ ) and completely different according to bacterial cells.

A large number of somatic cells reduce economic efficiency a stated by researchers (Milk and milk processing industry: Ukraine, 2007, p.126-127). So producer's efforts have to be focused at their decrease and thus milk quality increase. It allows to increase price level for raw milk. 
According to Ukrainian standards, milk with the quality of cells up to 300000 cells per $\mathrm{ml}$ is of high quality, 500000 - the first quality and $3 \mathrm{mln}$ - the second quality. In world's leading milk producer countries the requirements are much higher. In most EU countries and the USA the level of the researched index is up to 100000, in Australia, New Zealand, Denmark and Sweden - up to 50000 and Argentina - up to 25000 cells per ml (Figure 3). So farmers in such countries would not be able to sell the milk for processing companies with Ukrainian quality level (see Figure 3.).

Figure 3: Quality standards, thousands bacterial cells per ml

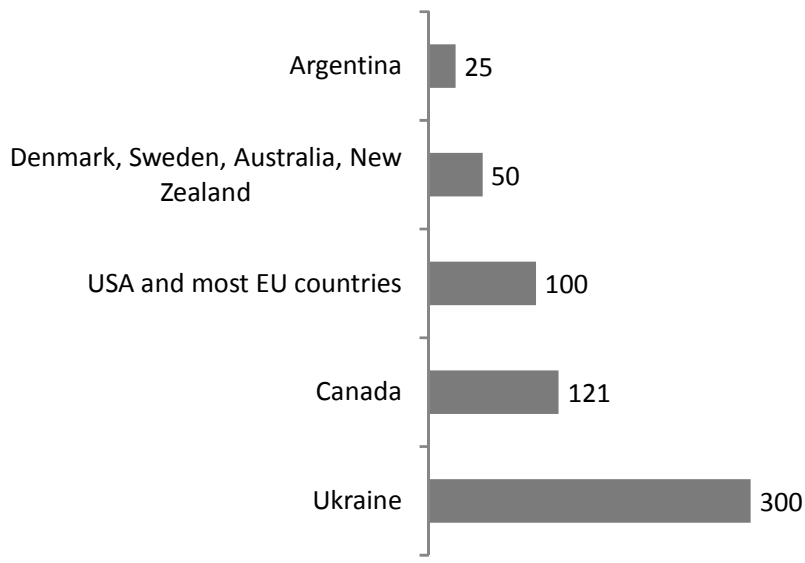

Source: Own construction

Next problem is average milk fat rate. In 2011 In Ukraine it was 3,56\% that is much less than in most EU countries where the researched index reached 4,3\% (Figure 4). Similar situation is with protein in milk. Its rate in Ukraine is much less than in EU countries.

Figure 4: Average milk fat rate, $\%$

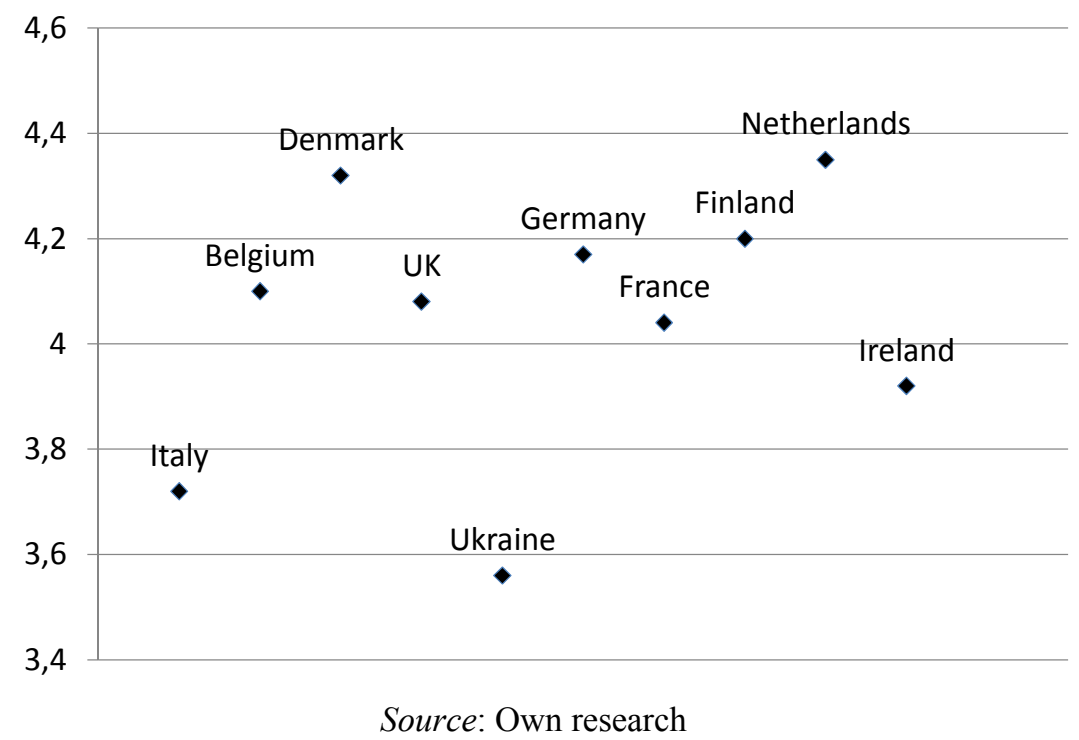


However upgrading not necessarily means the increasing of economic efficiency. With the increasing of additional costs on a production, in particular improvement of quality, the economic effect will grows. Economic efficiency grows only to the certain moment, when maximal recoupment of costs is provided. Since economic efficiency from additional costs begins to diminish, the personal interest goes down in further development of production. Thus, the necessity of determination of optimal additional charges appears on development of production, including improvement of quality of raw material.

Our suppositions are confirmed by developments of academician, Shpychak, which marks that „upgrading of products of concrete commodity producer is justified only in the case when receipts from realization of high-quality products will be higher comparatively with charges on her production" (Shpychak et al., 2000, p. 74). Investments in the improvement of quality are expedient only to that moment, when the rates of increase of realization price exceed the rates of increase of production cost.

Zubets and other scientists assert that composition and properties of milk depend on many factors among which forage and terms of maintenance have a major value. High yields and the best quality are predefined by a feed balancing, rational use of set of present in an economy forage and their preparation. Combination is in the ration of dairy cows of albumens, grew fat, carbohydrates, mineral matters, vitamins and other component parts it must be optimal and provide normal metabolism in an organism. On composition and properties of milk such factors influence yet and, as a breed and age of animal, her the physiology state, stage of lactation, disease on mastitis and other illnesses and others like that (Zubets et al., 2004, p. 530).

On information of Larry Chase, professor of animal breeding of Cornell University (USA), which was promulgated at International conference the „Milk rivers”, that took place in Travneve village Dnipropetrovsk region (Ukraine) on the base of agro company „Agro-Soyuz”, the determinative of quality of milk is a genotype of animals, her breed, intensity of plant-breeding process in a number of generations. Genetics predetermines $50 \%$ of variability amount of protein and fat, namely these indexes and influence on a purchase price on milk (Kudravtseva, 2007, p. 131).

As the Russian scientists Ryadchykov, Podvorok and Potyehin assert, in an order to achieve cow, it is necessary correctly to organize feeding of animal. For the calculation of necessity of cows in nutritives apply a factorial method and such basic indexes: nutrient energy of food value of forage, requirement of cows in exchange energy, on a life-support, milk producing and pregnancy (Ryadchykov et al., 2007, p. 31-33).

During 2005-2011 average purchasing milk prices increased by 2,7 times and reached 3042 UAH per tonne in 2010 (Figure 5). In 2011, this trend continued and the prices have reached $4000 \mathrm{UAH}$ per tonne in some regions. So the prices reached EU level and we cannot say that low level of milk production efficiency could be explained by low prices.

Although prices are increasing incessantly, milk profitability is changing from year to year. It means that there are factors that influence the profitability. The main ones are: fuel costs, livestock feeding, machinery for milking and fodder production and storage, etc. 
As a result, in $2011,62,3 \%$ of milk producers were profitable and $37,7 \%$ could not cover the production costs. The average level of production costs that allowed getting a profit was about $2265 \mathrm{UAH}$ per tonne.

Figure 5: Milk prices, UAH per tonne

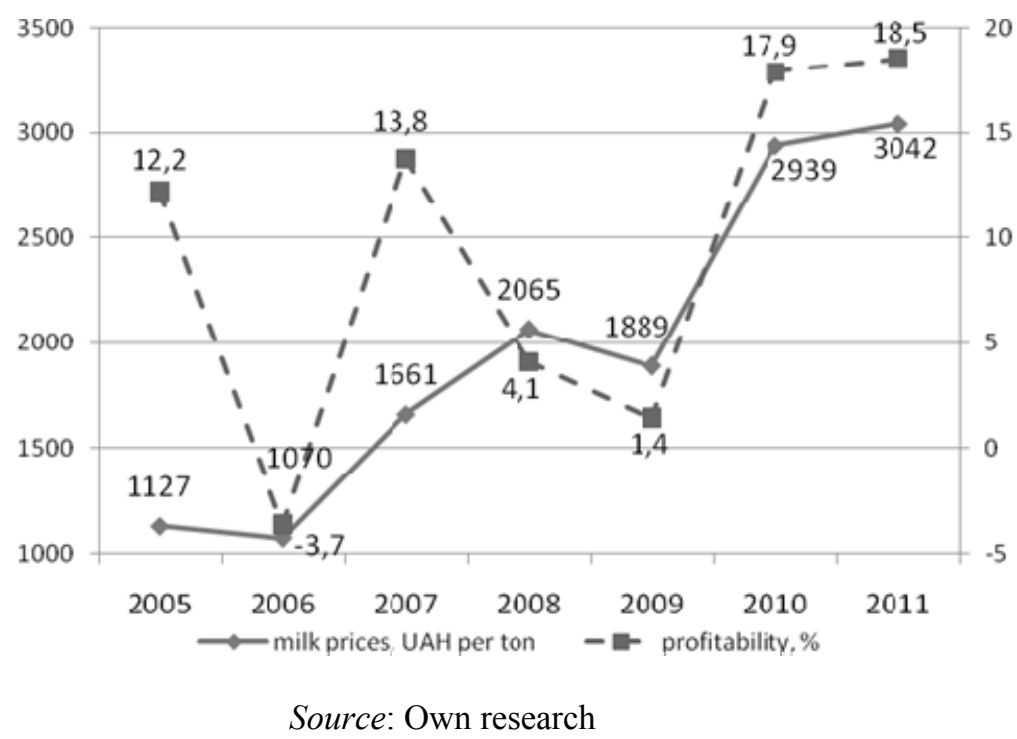

As a result, milk prices almost attained the level of the leading countries of world market of milk. If during 2005-2007 a price on milk in Ukraine was below, than in the countries of European Union and USA, then in 2008-2010 they were almost the same as the level of the USA, and in 2010 even exceeded it (Figure 6). According to my opinion, to promote purchase prices on milk will not be the effective measure of providing of profitability of agricultural commodity producers. As it will become important pre-condition of increase of cost of the prepared products and negatively will influence on a competitiveness in the world market.

Figure 6: The purchase price for raw milk, Euro / kg*

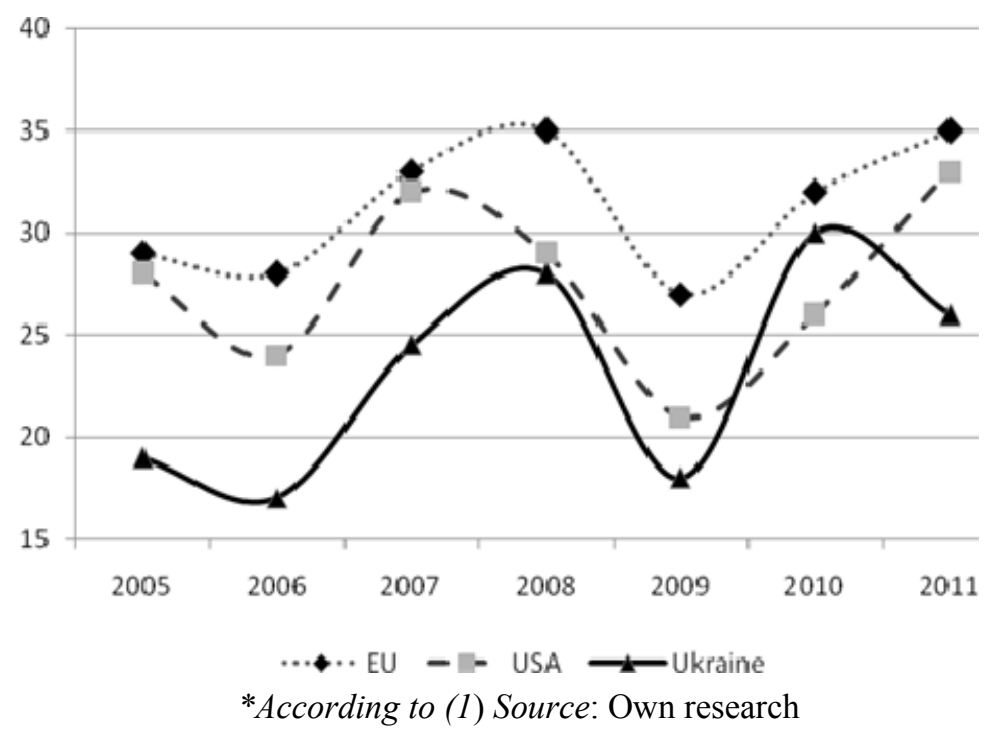


On efficiency of production of milk substantially infuses into seasonality of agricultural production, and also seasonality of supply of raw milk-material to processing and purveying organizations. In a summer-pasture period, the level of production of milk considerably increases by comparison to a winter period (Figure 7). As a result of considerable volume of suggestion, and also of short duration shelf-life of dairy products realization prices will go down. In winter, there is a reverse situation: the level of production diminishes, and the consumption of products increases almost on $20 \%$, that is why prices grow to $40 \%$. Therefore, such phenomenon as seasonality substantially influences on the processes of pricing on milk, economic efficiency of branch and market of dairy products development.

Figure 7: Monthly dynamics of milk production and purchase milk prices

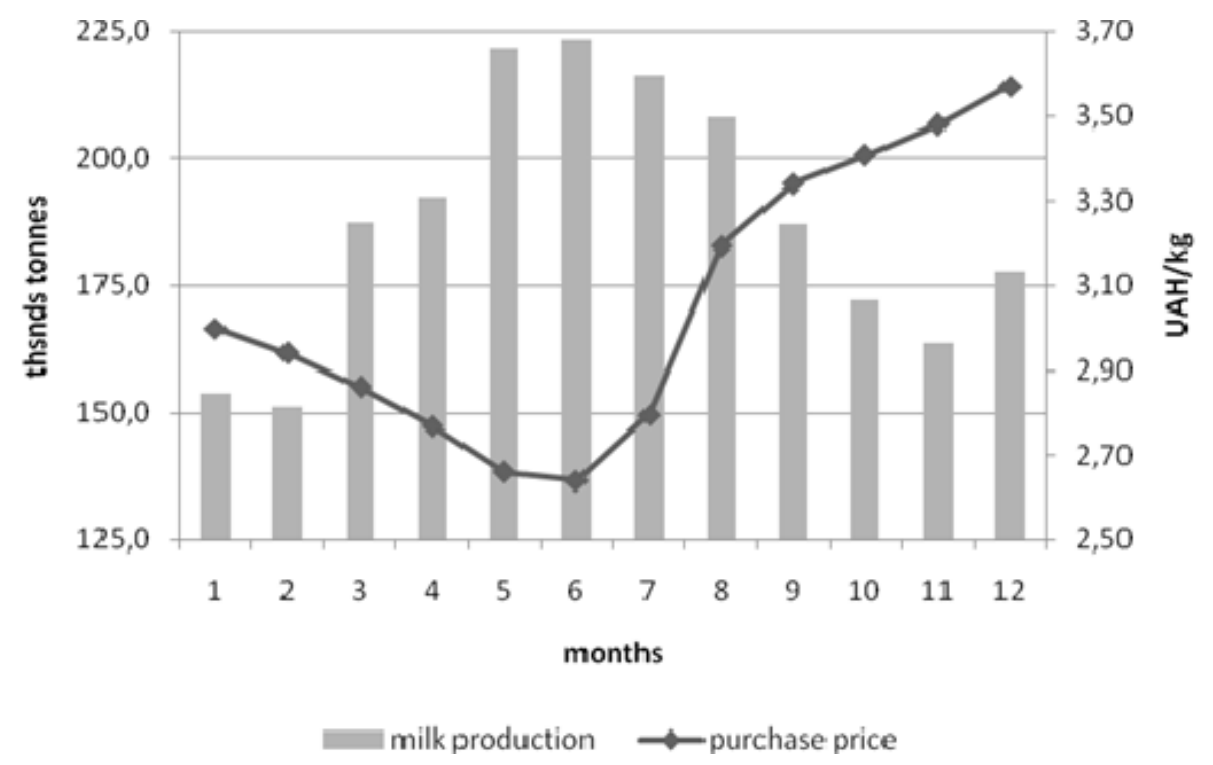

Source: Own research

Important reason of such sharp vibrations can be miscalculations in the system of organization of production. Through the shortage of facilities and possibilities for effective development, most of agricultural enterprises plans mass calving of cows on a spring-summer period, when upkeep of cattle and his feeding costs diminish due to the use of summer grounds and green mass. It allows producers partly to settle a situation with the necessity of resources, but negatively influences on the level of price on dairy raw material. Profitability of the dairy cattle breeding diminishes hereupon. Thus, by the decision of problems by such method commodity producers sharpen a yet more problem in branch.

An important factor, which influences on the volume of demand on milk is purchasing power of population. The income level of considerable part of population of Ukraine is at low level that results in insolvency to purchase necessary foods.

The conducted analysis showed that the level of production in Ukraine during 20052011 had exceeded the level of consumption of milk (Table 1). The level of selfsufficiency hesitated within the limits of $117-129 \%$. Thus, to the $30 \%$ volume of milk 
exported to other countries, that, certainly, is a positive tendency which promotes economic efficiency of production of milk substantially. A consumption at the level of $52-60 \%$ from a scientifically reasonable level testifies to the necessity of the increase of internal market of milk. It will allow heaving up the culture of consumption of dairies, and also will help in the decision of question of food safety of country. In 2011 every citizen consumed $147,5 \mathrm{~kg}$ on the average less thana scientifically reasonable level. For providing of internal demand at existent norms, it is necessary to produce additionally about 7 million tonnes of milk at the unchanging volumes of export and import of dairy products.

Table 1: Production and consumption of dairy products in Ukraine

\begin{tabular}{|l|r|r|r|r|r|r|r|}
\hline \multicolumn{1}{|c|}{ Index } & \multicolumn{7}{|c|}{ Year } \\
\cline { 2 - 8 } & $\mathbf{2 0 0 5}$ & $\mathbf{2 0 0 6}$ & $\mathbf{2 0 0 7}$ & $\mathbf{2 0 0 8}$ & $\mathbf{2 0 0 9}$ & $\mathbf{2 0 1 0}$ & $\mathbf{2 0 1 1}$ \\
\hline $\begin{array}{l}\text { Production of dairy products per } \\
\text { capita, kg }\end{array}$ & 291,1 & 284,0 & 263,6 & 254,3 & 252,1 & 245,2 & 242,5 \\
\hline $\begin{array}{l}\text { Consumption of dairy products per } \\
\text { capita, kg }\end{array}$ & 225,6 & 234,7 & 224,6 & 213,8 & 212,4 & 206,4 & 204,9 \\
\hline $\begin{array}{l}\text { The level of self-sufficiency by } \\
\text { domestic production, \% }\end{array}$ & 129,0 & 121,0 & 117,4 & 118,9 & 118,7 & 118,8 & 118,4 \\
\hline $\begin{array}{l}\text { The level of self-sufficiency } \\
\text { scientifically reasonable level of of } \\
\text { dairy products consumption, \%* }\end{array}$ & 57,8 & 60,2 & 57,6 & 54,8 & 54,5 & 52,9 & 52,5 \\
\hline
\end{tabular}

*According to the data of Kiev Research Institute of Food Hygiene of Dairy Products a scientifically reasonable level of dairy products consumption is $390 \mathrm{~kg}$ per capita.

Source: Own research

Most regions of our state produce milk more than their habitants consume. After attitude of consumption of milk toward his production of regions of Ukraine it is possible to divide into 3 groups:

1. Regions which do not provide the internal demand are Autonomous Republic of Crimea, Dnipropetrovsk, Donetsk, Kyiv and Kharkiv.

2. Regions which provide own demand with a possible insignificant export Zakarpattia, Zaporizhzhya, Luhansk, Odesa.

3. Regions which provide internal demand and export the considerable volume of milk - Vinnytsya, Volhynia, Zhytomyr, Ivano-Frankivsk, Kirovohrad, Lviv, Mykolaiv, Poltava, Rivne, Sumy, Ternopil, Kherson, Khmelnytsk, Tcherkasy, Chernivtsi and Chernihiv

Economic efficiency of milk product subcomplex depends on the results of economic activity of commodity producers, processing enterprises and sphere of realization of the prepared products. Unfortunately, now there was a situation, when commodity producers (almost 40\%) do not even cover an expense on the production of products, and processing and trade enterprises get considerable incomes. Such situation is not normal, as interest is lost to the production of raw material. The level of production of milk diminishes, the workload of processing powers, which brings an increase over of realization price to the increase of prime price of processing of milk, diminishes as a result. It in turn yet more substantial diminishes demand on milk in the conditions of the limited purchasing power. Reduction of 
volumes of realization of milk on processing results in diminishing of volumes of cash receipts to the commodity producers and income in this branch.

The important condition of increase of economic efficiency is the development of economic mutual relations of production with processing. Practice testifies that powerful processing enterprises render a various help to the producers: supply of the improved and new equipment for the roughing-out of milk, providing, financing of the field works necessary expensiv materials (filter and washing facilities) etc. Such help foresees returning of payment through supplying with dairy raw material. Thus, developing a fruitful collaboration with producers, processing enterprises form the source of raw materials for loading of own production capacities.

Creation of integration agroindustrial associations will allow substantially promoting efficiency of production of milk. As in such associations combination of interests of all participants of market of milk registers: the assured sale is put right, the level of loading of production capacities rises, transport-purveying charges diminish, the greater assortment of the prepared dairy products is produced.

As a result, consumers get competitive products the cost of this may be answered by their purchasing power. The level of consumption and realization of the prepared products rise and provide economic efficiency of all enterprises of dairy branch. Integration intercommunications can arise up between different enterprises on all stages of passing of mine-out raw material on processing and to end-user in end-point (Figure 8).

Figure 8: The scheme of economic relationship between key participants of milk market

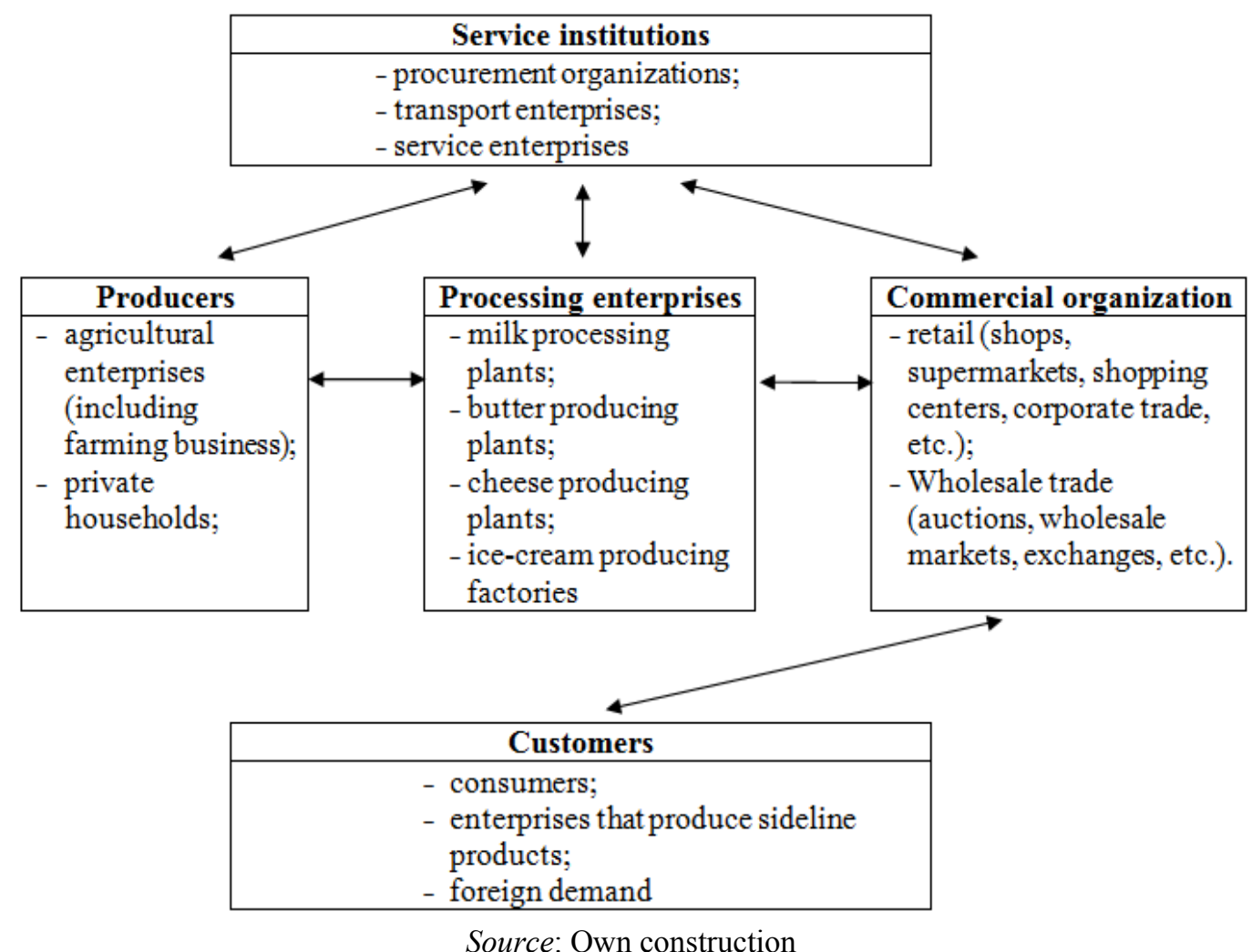


I agree with the statement of Levchenko that the problem of increasing the economic efficiency can be decided only in the case of creation of powerful stockraising complexes and intensive production of milk on industrial basis. It confirms a world tendency is the annual diminishing of amount of small farms (Levchenko, 2006, p. 4). Processing enterprises are simply forced to buy in milk in a private sector through diminishing of his production volumes in agricultural enterprises.

By the evolutional way of development of the dairy cattle breeding and increase of him economic efficiency there is adjusting of mutually beneficial connections between agricultural enterprises and private farms by peasant farms which produce milk. It is thus necessary to foresee enlargement of private production and its reorganization in the domestic farms of farmer type.

Organizational unit of combining efforts of private commodity producers can be creation of milk cooperative stores on the base of agricultural enterprises. Activity of such economic structures will enable to promote efficiency of forming of suggestion at the market of milk and to promote economic efficiency of the dairy cattle breeding the same. Such idea is supported by Andryushenko (2006), which specifies that one of important directions of development of agricultural production there is activation of co-operative motion in rural area.

In a Table 2, comparative description over the activity of farms is brought at the individual and co-operative production of milk.

Table 2: The comparative characteristics of businesses under individual and cooperative milk production

\begin{tabular}{|c|c|c|}
\hline Type of services & Individual farming & $\begin{array}{c}\text { Family farm business that operates } \\
\text { under cooperation }\end{array}$ \\
\hline Resource attracting & Under market conditions & Formation of bigger volume \\
\hline $\begin{array}{c}\text { Sales of production } \\
\text { Use of financial } \\
\text { resources }\end{array}$ & $\begin{array}{c}\text { Unstable with lower prises } \\
\text { entirely }\end{array}$ & $\begin{array}{c}\text { Organized, guaranteed, by contractual } \\
\text { obligations and relatively higher prices }\end{array}$ \\
\hline Management & Provided by owner & $\begin{array}{c}\text { According to engage in the production } \\
\text { and sales }\end{array}$ \\
\hline Risk share & Owner has unlimited \\
liability & $\begin{array}{c}\text { The responsibility is shared among the } \\
\text { participants }\end{array}$ \\
\hline
\end{tabular}

Source: Own research

Due to co-operation and increase of level of the concentration of individual farms have possibilities for the receipt of additional economic values. To one of the most essential it is possible to take bringing in of productive resources on more subzero prices due to the greater volume of purchase, production distribution after comparatively by higher prices through forming of wholesale parties, distribution of risk et cetera.

Azizov suggests that co-operation which executes two functions, economic and social, is the important mean of realization of economic interests and social defense of her participants. An economic function consists in that on the basis of combining effort of collective or individual commodity producers the real terms are created for the 
considerable increase of efficiency of the use of productive resources, all production the results of which belong to only his participants, and they can by them boss only. Co-operation, providing legal and economic independence of every commodity producer, enables to promote the concentration of production to the optimal sizes on separate him the technological stages. The social function of co-operation is sent to defense the interests of peasants. In the conditions of market economy, competitive activity of commodity producers for production distribution acquires sharp character. Therefore, co-operation becomes the effective enough mean of defense of shallow peasant commodity producers from large monopolistic associations, which aim to extend and control through monopolization of markets of sale of sphere of influence on a production. An extraordinarily important value is acquired by co-operation in creation of social infrastructure on a village, alteration of social terms of life of peasants. In co-operation, the commodity producers find the social protecting from influence of the tax system, realization of public and commercial credit policy (Azizov et al., 2001, p. 227)

The important purpose of cooperative store can be providing of additional profits for his participants due to the increase of purchase price as a result of roughing-out of dairy raw material (cooling). Basic activity will be sent to the association of the personal peasant farms of population, purchase in them milk and him roughing-out. Auxiliary activity will be formed due to providing of artificial insemination and veterinary service, consultative services, organization of transporting etc.

Basic economic performance indicators of service cooperative in the dairy cattle breeding are represented in a Table 3.

Table 3: Main indexes of economic activity in the service dairy farming cooperative

\begin{tabular}{|l|r|r|r|}
\hline \multicolumn{1}{|c|}{ Index } & \multicolumn{2}{c|}{ Variant } \\
\cline { 2 - 4 } & $\mathbf{1}$ & $\mathbf{2}$ & \multicolumn{1}{c|}{$\mathbf{2}$} \\
\hline The number of dairy cows in the cooperative, heads & 100 & 200 & 300 \\
\hline The volume of milk bought from producers, kg/day & 1200 & 2400 & 3600 \\
\hline Annual gross income results, thousand UAH & 1533,0 & 3066,0 & 4599,0 \\
\hline Annual economic results, thousand UAH & 525,6 & 1051,2 & 1576,8 \\
\hline
\end{tabular}

Source: Own research

Calculations were conducted under different scenarios which differed in the quantity of milking cows in a cooperative store from 100 to 300 and accordingly by the volume of the provided milk - from 1200 to $3600 \mathrm{~kg}$ in a day. A calculation purchase price on dairy raw material in the personal peasant farms folds $-2,3 \mathrm{hrn} . / \mathrm{kg}$, realization prise for processing enterprises $-3,5 \mathrm{hrn} . / \mathrm{kg}$

In end-point from functioning of cooperative a calculation economic result will fold from 262,8 a thousand hrn. to the almost 1,6 million hrn. depending on the volume of the provided milk.

Hubskyy asserts that farmer co-operation (from lat. cooperatio is a collaboration) with the purpose of agricultural production of most development distribution purchased 
in the end of $19^{\text {th }}$ to beginning of the $20^{\text {th }}$ century as an alternative to the private monopolized system of processing industry. This was a practical step to her demonopolization. In most countries co-operation has a multilevel branch structure within the framework of which an agricultural produce passes a way from a farm to the wholesale and retail network of trade, where the prepared foodstuffs will be realized. On the basis of such structure, there is principle of horizontal and vertical concentration of co-operative business (Hubskyy, 1998, p. 12-13).

I support opinion of Parhomets, which states, that in milk business of EU countries a tendency to the increase of concentration of production in processing enterprises shows up. For example, to such stores-giants, as „MD Foods” in Denmark, „Sodiaal” in France, „Milk Marque” in Great Britain, „Arla” in Sweden repressing part of market of milk and dairies belongs in their countries. The large concentration of milk business enables to the cooperative stores to use the most modern technologies of processing, pursue a flexible commodity policy, get access to the international markets, combine milk business with a material and technical supply and other important services, to weaken negative influence of seasonal vibrations in the production of milk (Parhomets, 2003, p. 64).

Sabluk and some other scientists assert that at an international level there are two base determinations of co-operative societies. The first determination is offered by International Co-operative Alliance, the second is by International Organization of Labour. Both will not obligate the co-operators of different countries to apply exactly these determinations: they only carry out the role of recommendations and referencepoints in preparation of projects of co-operative laws.

According to the first determination, a cooperative store is an independent association of persons with the purpose of satisfaction of the social and economic necessities and aspirations through an enterprise which is common property and controlled democratically. As a rule, such determination is complemented by the list of international principles of co-operation. However, many countries are inclined to use determination of International Organization of Labour and accede approximately to such definition: a cooperative store is an association of persons, which voluntarily teamed up with the purpose of satisfaction of general necessities by formation of the democratically controlled enterprise and did equivalent payments in the capital of the society and consented to divide a risk and benefit from activity in which they participate (Parhomets, 2005, p. 14).

So efficient milk production development could be reached by optimal use of resources (material resources, labour and finance) and modern methods of production organization (management, control, animal breeding, feeding, veterinary and hygiene). It enables to increase milk yield and improve the quality of milk raw. It will help to decrease the unit production cost and increase purchasing price. It will result in the increase of milk production efficiency and the provision of a competitive ability of Ukrainian dairy products at a world market. 


\section{Conclusion}

Ukrainian milk production has very comfortable future prospects. There are some negative trends in milk branch but according to my opinion, they will change due to world market situation. Current market situation enables to increase milk price that in its turn influence on producer's motivation. One of the important problems of domestic milk production is milk raw quality. The limited amount of agricultural companies have possibilities to provide all necessary resources to get a milk of extra class despite the fact that Ukrainian standards requirements are lower than Europeans ones.

The shortage of financial resources is a very important problem of efficient development of milk production. It affects the milk production especially in peak seasons. The bank loans are very expensive in Ukraine therefore it is very difficult to get them for the majority of enterprises.

Stable milk supply formation depends on many factors. Some of them could be solved by agricultural producers and some may require for a government regulation. So milk production needs the integration of all participants of milk products subcomplex to achieve its competitiveness in world market.

Milk product subcomplex of Ukraine has sufficient potential for development. Favourable climatic conditions, comparably more subzero cost of forage and labour enable to assert that our state has serious possibilities and ponderable potential in an order to take the main place among countries-leaders from the production of dairies. For this purpose, it is necessary acceptance of innovative decisions in relation to introduction of modern technologies of production and his enlargement. But the dairy cattle breeding is in such position, when agricultural enterprises cannot independently work out existent problems to want of financial resources for the extended recreation. Therefore, for increasing the efficiency of production of milk and providing of population products for consumption at the level of scientifically reasonable norms an intervention is necessary from governmental institutions. The self forming of effective, effective mechanism of state support of dairy industry will allow to create necessary terms for providing of competitiveness of the Ukrainian dairy products on world markets.

\section{References}

1. LTO (2012): LTO International comparison of producer prices for milk - 2011 / LTO Nederland, $25 \mathrm{p}$.

2. Azizov S.P., Kaninsky P.K., Skupyy D.V. (2001): Organization of production and agrarian business in agricultural enterprises - Kyiv, IAE, $834 \mathrm{p}$.

3. Andryushenko A.M. (2006): Economic efficiency increase of agricultural production cooperatives. - Economics of AIK (Agro Industrial Complex). - №8.- p.60.

4. Berezivsky P.S. (1998): Economic efficiency of livestock breeding and the ways if its increase. - Lviv: Ukrainian technologies, $156 \mathrm{p}$.

5. Hubskyy B.V. (1998): Agricultural market. - Kyiv, Nora-print, 184 p.

6. Ilchuk M.M. (2004): Effective functioning of milkproduct subcomplex of Ukraine. - Kyiv, Nichlava, $312 \mathrm{p}$. 
7. Kravtsiv R. Y., Khomenko V.I., Ostrovsky Ya.Yu. and others (2001): Milk and milk products. - Lviv: LA „Pyramid”, $312 \mathrm{p}$.

8. Kudravtseva L. (2007): Ration and cow milk quality // Supply, №4, p.130-131.

9. Levchenko V.I. (2006): The prospects of milk production - intensive way at the industrial base // Agrarian news, №2, p.4-6.

10. Ukrainian club of agrarian business. (2008): Milk and milk processing industry: Ukraine 2007 / Ukrainian club of agrarian business. Kyiv, Logos, 232 p.

11. Musyka P., Domansky A., Cherevko G., Gavuka I. (2010): Milk and milk products market // Agrarian economy. V.3. - №1-2. p.14-27.

12. Zubets ez al. (eds) (2004): Scientific principles of agroindustrial production in the Foreststeppe zone of Ukraine. Kyiv, Logos, 776 p.

13. Parhomets M. K. (2005): Organizational and economic bases of milk product development under market conditions. Ternopil, Economic thought, $346 \mathrm{p}$.

14. Ryadchykov V., Podvorok N., Potyehin S. (2007): Feeding high-yielding cows. - Livestock of Ukraine. - №1.

15. Sabluk, P.T. ; Boyko, V.I. (eds) (2005): Economics of milk production in Ukraine. Monography/ - Kyiv, IAE, $340 \mathrm{p}$.

16. Agricultural cooperation: the essence and problems of the development in Ukraine. - Kyiv, IAE, $166 \mathrm{p}$.

17. Agriculture of Ukraine. Statistical yearbook 2010. (2011): Kyiv, State committee of Statistics of Ukraine, 2011. - $386 \mathrm{p}$.

18. Shpychak O.M. et al. (eds) (2000): Prices, expenditures, profits of agricultural enterprises and food market infrastructure. Kyiv, IAE, $585 \mathrm{p}$. 